\title{
Africa's response mechanisms to the ramification of COVID-19
}

\section{Chinenye Ezeh ${ }^{1}$ and Patrice Monkam ${ }^{2}$ and Amatus Gyilbag ${ }^{3}$ and Joseph Jonathan Magoua ${ }^{4}$ and Mwichie Namusamba ${ }^{5}$ and Pius Babuna ${ }^{6}$}

\begin{abstract}
The ongoing crisis of COVID-19 pandemic that swept across the world, poses serious challenges on health delivery systems particularly in developing countries. In Africa however, the crisis rather inspires and sparks creativity and innovation at the national, institutional, organizational, and individual levels. This paper unravels Africa's response mechanisms to the virus that might have relatively contributed to the low infection rate of the pandemic within the continent. Some criteria are adopted to assess and assemble the most influential government policies and home-grown innovations from various African countries and territories within the continent. It is found that, some of the innovations do not only help in combating the virus, but also have socio-economic benefits as they substantially complement government efforts in easing the burden of the citizenry as they cope with preventive protocols imposed on them. This study will be helpful in identifying the most significant home-based innovations that can be improved and used to reduce health delivery crises within the continent even after COVID-19.
\end{abstract}

\section{Keywords}

COVID 19, Response strategies, African continent, Pandemic, innovative solutions

\section{Introduction}

From the onset of COVID-19 pandemic, there had been great preparedness to prevent circumstances that came with it as compared to 100 years ago. This readiness and advanced capabilities in prevention, surveillance, diagnostics, and treatments to respond to the COVID-19 pandemic were fostered by scars of past pandemics such as the 1918 H1N1/Spanish flu pandemic Jester et al. (2018), Ebola disease and several others Otu et al. (2017). The prevention of severe diseases and reduction of the related death rate are of primary objectives United Nations (2020a), and have fostered massive research ranging from COVID-19 etiology to treatment and vaccine development Centers for Disease Control \& prevention (2020); Cascella et al. (2020); Guo et al. (2020).

Before its arrival in Africa on 14th February, 2020 in Egypt Kantis et al. (2020), COVID-19 pandemic had caused global havoc in Asia, Europe, South America and North America. Subsequently, new cases were reported in Algeria on 25th February, 2020, Nigeria on 27th February, 2020, Tunisia and Senegal collectively on 2nd March, 2020 Kantis et al. (2020). As at 10th November 2020, the total number of recorded cases and total number of deaths in Africa are estimated at 1,362,566 and 30,666 respectively World Health Organization (2020). There have been various negative socio-economic consequences of the global pandemic for Africa, but not as severe as predicted by the United Nations (UN), World health organization (WHO) and the World Bank GroupUnited Nations (2020b); World Bank Group (2020). The most crucial of these consequences include GDP drops , collapse of domestic supply chains, stalled economic activities, loss of lives, breakdown and disrupted social services, societal unrest, political violence and so on United Nations (2020c). However, there have been myriad of steps taken by African governments to address these consequences, which are worth exploring.

The African continent has demonstrated remarkable preparedness and response execution for curbing the novel pandemic. A number of researchers have written to offer their views about the level of preparedness by various African governments as well as the pragmatic steps that have been deployed to tackle COVID-19. In a recent letter, Otu et al. (2020) Otu et al. (2020) examine the level of preparedness of Africa to withstand the COVID-19 pandemic, resulting in some recommendations whose strict adherence could

${ }^{1}$ College of Information Science and Engineering, Northeastern University, No.195, Chuangxin Road, Hunnan District Shenyang, 110169, China

${ }^{2}$ Easysignal Group, State Key Laboratory of Intelligent Technology and Systems, Tsinghua National Laboratory for Information Science and Technology, Department of Automation, Tsinghua University, Beijing 100084, China

${ }^{3}$ Chinese Academy of Agricultural Sciences (CAAS), Institute of Environment and Sustainable Development in Agriculture (IEDA). Haidian District, Beijing, China

${ }^{4}$ Department of Construction Management, Tsinghua University, China ${ }^{5}$ College of Life Science and Health, Northeastern University, 195 Chuangxin Road, Hunnan District, Shenyang, Liaoning Province 110819, People's Republic of China

${ }^{6}$ School of Environment, Beijing Normal University, Beijing, 100875, China

\section{Corresponding author:}

Chinenye Ezeh, College of Information Science and Engineering, Northeastern University, No.195, Chuangxin Road, Hunnan District Shenyang, 110169, China.

Email: noblenenye@gmail.com 
help keep the scourge at minimal levels. Ihekweazu and Agogo (2020) reported on the undertaking of joint external regulation (JEE) of international health regulations (IHR) by African countries. This step was necessary to help them discover holes that needed to be plugged in their capacity to handle health crises when the need surfaces Ihekweazu and Agogo (2020). Osseni (2020) reported on the measures put in place by the African Union (AU) to tackle COVID-19 across Sub-Saharan Africa (SSA). Some of these measures include the establishment of Africa Task Force on Coronavirus Preparedness and Response (AFCTOR), in collaboration with Africa Centers for Disease Control and Prevention (Africa CDC) and Southern Africa Center for Infectious Disease Surveillance (SACIDS) Osseni (2020); Loembé et al. (2020). In addition, it is worth noting that the testing capacities around Africa have been ramped up by the establishment of PACT (Partnership to Accelerate COVID-19 Testing); Trace, Test \& Track (CDC-T3) by the AU and Africa CDC Osseni (2020). Furthermore, it was reported that the late arrival of COVID-19 in the African continent afforded the governments and other stakeholders the opportunity to improve their preparedness beforehand Loembé et al. (2020). One of the significant efforts made by the collaboration between AU, WHO, Africa CDC and West Africa Health Organization was to establish more testing laboratories across Africa. Such testing laboratories rose from 2 to 43 sometime between February and middle of March, 2020 Loembé et al. (2020).

It is noted that many studies have reported on the level of preparedness and response strategies of African countries to tackle the impacts of COVID-19 pandemic. However, none of them has examined in great details all of Africa's responses to COVID-19. Specifically, existing works mainly focused on either a specific region or country, without investigating the entire continent.

This paper presents detailed analysis of the most prominent response mechanisms adopted across the African continent to tackle the damages of the COVID-19 pandemic. Specifically, the aim is to unravel Africa's response mechanisms to the novel pandemic by assembling the most influential government policies and home-grown innovations from various African countries. Furthermore, the effectiveness of these response strategies is thoroughly assessed. Finally, key recommendations for boosting the readiness and resilience capability of African countries to tackle outbreaks are put forward.

\section{Methodology}

COVID-19 took the world by storm, but African continent comparatively recorded the lowest case count with the lowest infection rate. Substantially, there seems to be a reciprocal association between the spread of COVID19 and proactive combat strategies. In this regard, we believe that an insightful analysis of the containment strategies deployed in various African nations would be of great importance in understanding the current state of the ramification of COVID-19 across the continent. Specifically, this work seeks to unravel Africa's response mechanisms to the virus by adopting some criteria to assemble the most influential government policies and homegrown innovations from various countries and territories within the continent. These assembling criteria include significant positive impact, testing and certification by experts, and approval by high institutions, etc. In other words, these policies and innovations are recognized by Africa CDC to have contributed significantly in fighting the virus. The innovations are those tested and certified, and in some countries, produced in large quantities for distribution to other parts of the sub-region. In addition, it is worth noting that relevant scientific literature and reports from $\mathrm{WHO}, \mathrm{UN}$, the World Bank, and many others have been consulted to complement our assessment and discussions of these policies and innovations.

\section{Government socio-economic policies}

In a bid to arrest the menace of COVID-19 across the African continent, almost all the 54 countries' governments and territories rolled out helpful policies suitable to their situations. These inlcude:

\section{Adoption of state of emergency}

In other to ease the management of COVID-19, a nationwide state of disaster with the imposition of travel bans and restriction of movements into and within the country was declared by many African countries including South Africa (SA), Egypt, Tunisia, Mali, Niger, etc Schneidman et al. (2020b); Zawya (2020); Masbah and Jacobs (2020). Specifically, The SA government had issued a lockdown directive across the country, which took effect from the 27th day of March, 2020, resulting in the reduction of the infection rate by $3 \%$ daily Devermont and Mukulu (2020).

\section{Social distancing}

Given that the best way to curtail the spread of COVID19 is to break its chain of transmission Maringira (2020); Guti'errez-Romero (2020), most of the African countries started implementing social distancing policy as soon as they registered their first cases so as to limit the level of contacts among people. Thereafter, public health agencies and some celebrities kept urging the populations to stay safe and observe the social distancing policy for their own safety Ihekweazu and Agogo (2020). In addition, countries such as Algeria, Egypt, Zambia, Uganda, Nigeria, Ghana, Morocco, Kenya, Malawi, Zimbabwe, etc. had instituted policies that certain number of persons must not gather at events or public places at the same time Guti'errez-Romero (2020).

\section{Curfew, Lockdown and Shut-down}

Over 30 African countries had at some point instituted curfews, lockdown or shut-down in a bid to contain the spread of COVID-19 International Center for Not Profit Law (2020). However, it is worth noting that even though these policies were issued, they were not absolute in the sense that they were implemented in some selected cities. The Nigerian government as well as state governments issued night curfew in only few cities including Lagos, Abuja (FCT), Kaduna, Kano, etc. The Punch (2020). From March 23rd, the Federal Government of Nigeria suspended 
all international and domestic commercial air flights into and within Nigeria. In Tunisia, the government imposed lockdown and curfew on 22nd March, 2020 Fair Wear (2020). The Egyptian government issued curfews (partial and full), and lockdowns (partial and full), shut-down, borders closure, etc Zawya (2020). In Zambia, the government issued a temporary lockdown in some select towns in order to carry out tracing and testing KPMG (2020e). In March, 2020, Ghana's government implemented lock downs and bans on all public gatherings Akafia (2020).

\section{Postponement of general elections}

Some African countries scheduled to conduct general elections between 2020 and 2021. While some countries postponed their general elections, a number of others braved the odds and proceeded with their country's general elections. For instance, even in the face of the rampaging COVID-19, Burundi proceeded with their country's general election. Benin held local elections amid the COVID-19 scare. Campaign rallies were cancelled and voters were mandated to use face masks and observe social distancing as well at the polling units International Institute for Democracy \& Electoral Asistance (2020).

In some other countries, the COVID-19 pandemic hugely upset the election programs and left an atmosphere of uncertainty. For instance, the general elections that was initially slated for August, 2020 in Ethiopia was postponed with a wide consensus and some level of contentions about its constitutionality International Institute for Democracy \& Electoral Asistance (2020). In Nigeria, by-elections for some senatorial zones in Plateau, Imo and Bayelsa states were postponed indefinitely by the electoral umpire, Independent National Electoral Commission (INEC).

\section{Sentence and security measures adjustments in prisons}

In other to alleviate congestion in prisons and improve the efficiency of preventive measures such as social distancing, African governments implemented various compassionate imprisonment schemes. For example, in Ethiopia, over 4,000 prisoners were pardoned to decongest the prison system. In addition, given the precarious living conditions in Egyptian prisons, the Egyptian government implemented some sentence security measures and sentence adjustments to mitigate the spread of the virus. Specifically, visits to prisoners were suspended for some time and over 3000 prisoners had been pardoned and released Prison Insider (2020).

\section{Adoption of stimulus package}

Various economic measures have been taken by African governments to help their country's economy and to support their citizens. These measures include support for critical businesses, bridge financing, solidarity fund, employee support, unemployment insurance, tax subsidies, debt relief fund, bank relief etc. Some examples are as follows:

The South African government and other relevant agencies implemented some fiscal, monetary and other similar approaches to reinforce and sustain their economy, to provide succor for most economically vulnerable South Africans, to stabilize the economy, to protect jobs, etc. Schneidman et al. (2020a). The government of Zambia instituted a number of economic related measures to mitigate the problems of high food costs, high rate of unemployment, political tensions, low copper prices, temporary closure of mines, debt crisis, etc. Effective States \& Inlcusive Development (2020). The government further earmarked the sum of K57 million as Epidemic Preparedness Fund under the ministry of health. Aiming to reduce the socio-economic effects of COVID-19 pandemic on the Algerian society, Algerian authorities allocated a special budget (70billion dinars) for medical supplies, encouragement and reward to medical workers, equipment of health facilities, allowances to the unemployed, etc International Monetary Fund (2020). The Egyptian government adopted a $\$ 6.4$ billion stimulus package on 14th March, 2020 International Monetary Fund (2020), which was intended to be used for providing urgent and necessary medical supplies, rewarding medical workers, etc. On 15th March 2020, King Mohammed VI of Morocco instructed the establishment of an emergency fund, which resulted in the collection of over $\$ 3.2$ billion Masbah and Jacobs (2020). Some of these funds have been used to support vulnerable Moroccans and to purchase urgent and necessary medical supplies. The Tunisian authorities set up a $\$ 0.71$ billion plan to tackle the economic impacts of the pandemic International Monetary Fund (2020). This plan comprises many key actions including support to vulnerable citizens and low income households, support to temporarily unemployed people due to the pandemic, etc. affected by the pandemic. Also, many hospitals were provided with medical supplies through fundraising initiatives conducted by union members. The government of Gabon set up a fund with an initial donation of FCFA 4 billion (approx. USD 2 million) to help fight the pandemic. It equally set up a team resourced with $\$ 417$ million to support households and most vulnerable people through the payment of utility bills and support with free food organized by state to feed vulnerable people.

\section{Tax and loans adjustment}

Some African countries have given tax waivers to their countrymen as a way to cushion the effect of COVID-19. In Northern Africa, Algeria, Morocco and Tunisia allowed the postponement of declaration and payments of income taxes Near East South Asia (2020). In the region of Eastern Africa, the Ethiopian government launched tax exemption for importation of products related to curbing the outbreak and instituted an accelerated processing of VAT refunds to businesses Alemayehou (2020). In Central Africa region, the Camerounian and Chadian governments implemented some tax measures which include: tax reduction, suspension of ongoing and uncommitted tax audits; suspension of actions for unforced recovery and issuance of non remittance certificates to companies with unpaid taxes KPMG (2020a,b). In the Democratic Republic of Congo (Kinshasa), a number of tax measures have been implemented. They include: tax exemptions for six months in the production of pharmaceuticals and other medicinal equipment linked to the pandemic. Three (3) months suspension of Value Added Tax (VAT) collection on imports and sales of necessities or mass consumption products; suspension for 3 months, of payment of employee 
$\operatorname{tax}$ (IPR) on the remuneration and bonuses of civil servants; etc KPMG (2020c). In Egypt, the Central bank of Egypt (CBE) reduced their transaction rate by $3 \%$. Moreover, the authorities announced the availability of supports and loans for affected small projects and postponement of repayment of loans for citizens KPMG (2020d). In a similar fashion, the government of Morocco promised to provide its citizens with interest-free and low rate loans Masbah and Jacobs (2020). The government of Congo Kinshasa issued a policy to effect decrease in interest rates from 9.0\% to 7.5\% KPMG (2020c).

\section{External support to strengthen African governments' preventive measures}

In order to complement the African governments' efforts in fighting the pandemic, the international community assisted the continent in diverse ways. Specifically, Africa received both material and financial aids from the World Bank, the International Monetary Fund (IMF), USAID, the United Nations (UN), China, philanthropists, etc as short, medium and long-term support to help detect, prevent, and respond to the COVID-19 pandemic. Some details of these aids are as follows:

The World Bank made loans available to various African countries including Ghana (\$100 million) The World Bank (2020c), Senegal (\$20 million) The World Bank (2020b), Egypt (\$50 million) The World Bank (2020a), Tunisia (\$35 million) The World Bank (2020d), etc. The International Monetary Fund (IMF) in conjunction with the World Bank back in April, released a statement that the sum of $\$ 57$ billion had been mobilized to assist Africa to deal with the menace of COVID - 19 Fletcher (2020); Booth (2020). Interestingly, 19 countries in Sub-Saharan Africa got some debt relief as six months IMF debt repayment were cancelled and diverted to funds and resources to help them tackle COVID-19 Fletcher (2020). The US government contributed about $\$ 10$ million (K180 million) in health equipment to assist Zambia in boosting its responses against the COVID -19 pandemic. The United States government provided many governments with significant support: Zambia (\$10 million and medical supplies) U.S. Embassy Zambia (2020), Morocco (medical supplies) U.S. Embassy Morocco (2020), Tunisia (over \$25 million) U.S. Embassy Tunisia (2020), etc. The Chinese government and some Chinese philanthropists sent batches of aids in form of funds and medical supplies to all African countries and territories Maida (2020). Many Chinese medical expert teams were sent to Africa by the Chinese government to help them in the fight against the pandemic Maida (2020); Xinhua (2020). The Bill and Melinda Gates Foundation donated the sum of $\$ 20$ million to assist in the effectual scrutiny, contact tracing and quarantine, and setting up emergency operations centers across Africa. The Jack Ma Foundation equally supplied tons of medical equipment to all the African countries to enhance their fight against COVID-19 Loembé et al. (2020).

\section{Aid from local organizations and individuals}

There were contributions and support from kind spirited individuals and organizations towards supporting their country's efforts against COVID-19. As mentioned earlier, UGTT (the trade union) made some donations in Tunisia.
In Nigeria, a number of individuals and corporate organizations offered aids in various capacities. The donated sum is quite enormous and some of the notable donors include Emmanuel Lazarus (N2 billion), Aliko Dangote, Tony Elumelu, Femi Otedola, Abdulsamad Rabiu, Herbert Wigwe, Segun Agbaje, and Jim Ovie who each donated N1 billion cash to help the government in its emergency response plan Emmanuel (2020); Onyenaucheya (2020).

In Ghana, the Catholic Bishop's conference made a donation of 70000 cedis to support the country's fight against COVID-19 Maayaki (2020). Also, a number of companies and individuals have made donations of varied sums to the COVID-19 National Trust Fund in Ghana. Some of the companies include: Sunon Asogli Power Limited $(\$ 100$ 000), International Central Gospel Church (GHc100 000), Africa World Airlines Ltd (\$100 000) and so many more Effah (2020).

\section{Outstanding "home-grown" innovations against COVID-19}

Necessity is said to be the mother of inventions and the African continent has proved its mettle with some innovative responses against COVID-19. Some of the outstanding innovations are listed below:

\section{Rapid Diagnostic Test (RDT) kit}

In early stages of the propagation of COVID-19 pandemic in Africa, many African countries conducted tests based on PCR (Polymerase Chain Reaction). However, PCR based testing requires more time (approximately 48 hours) and tends to fail in detecting asymptomatic cases. Thus, to help achieve fast tracked testing of suspected COVID-19 cases, some Ghanaian scientists came up with innovative test kits. Specifically, scientists from Kwame Nkrumah University of Science and Technology (KNUST) developed a rapid diagnostic test (RDT) kit Ghana Web (2020), named 'COVID-19IgG/IgM Rapid Test molded in the form of a homemade kit used in glucose or pregnancy testing. The COVID-19IgG/IgM Rapid Test' requires only a finger-prick drop of blood. Another test kit developer, Incas Akorlie (2020), develops about 50,000 COVID-19 antibody test kits per week, for a retail price of about $\$ 5$. The local production of test kits came as a response to the growing skepticism regarding the authenticity of imported kits. Also, the low prices and considerable production quantities of these kits helped to alleviate the demand and supply in the country.

\section{$\$ 1$ test kit}

It has been proven that an effective management of the COVID-19 pandemic is significantly dependent on timely testing and tracing. Hence, many African countries made major strides in the area of innovations with regard to test kits. Some scientists in Senegal equally contributed significantly to the fight against COVID-19 with the development of test kits. The Institut Pasteur de Dakar, in collaboration with the British biotech firm Mologic developed rapid and affordable COVID-19 test kits Sarker (2020). This collaboration is part of the UK government's 


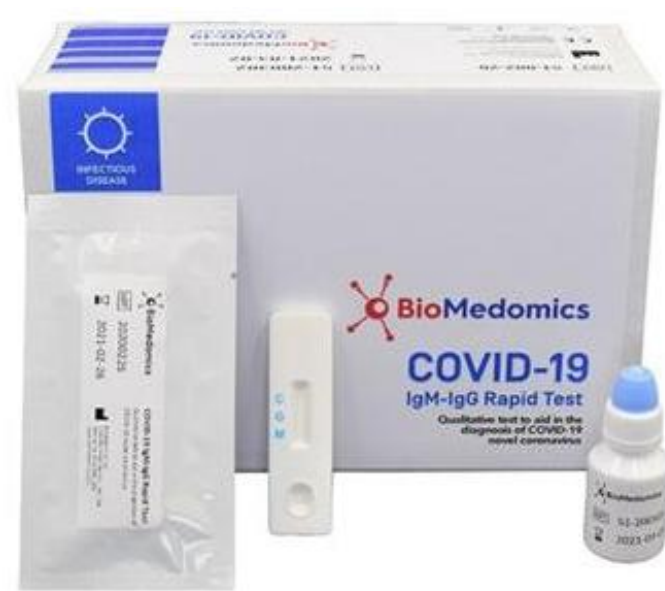

Figure 1. The COVID-19lgG/IgM Rapid Test kit developed by Kwame Nkrumah University of Science and Technology (KNUST) scientists.

$£ 46$ million (\$60 million) coronavirus prevention and research funding package, from which the government awarded a $£ 1$ million grant to Mologic. The result of this collaboration turned out to be a 10 minutes COVID-19 test kit for barely \$1 Osseni (2020); Loembé et al. (2020).

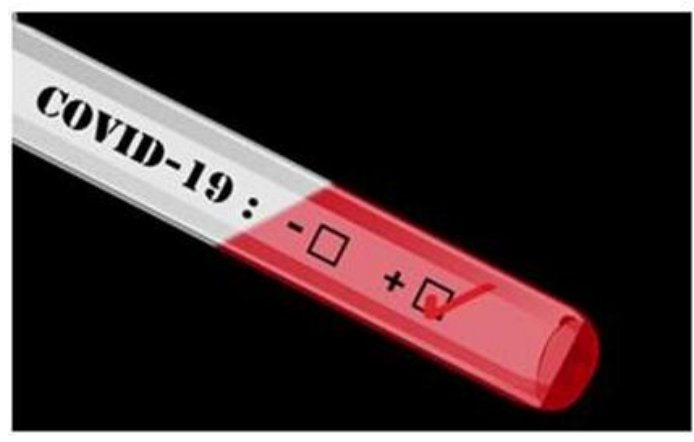

Figure 2. Rapid and affordable $\$ 1$ test kit. It can generate results in 10 minutes.

\section{Ventilators}

African scientists are braving the odds against this pandemic with the design, development and manufacturing of ventilators. In West Africa, there has been a remarkable Senegalese innovation of a 3D printed ventilator Ben-Hur (2020) that costs about $\$ 60$ (Sh6, 000) compared to imported ones which cost about $\$ 16,000$ (Sh1.6 million). In Kenya, prototype ventilators were developed by a multidisciplinary team of 25 engineers including students from Kenyatta University to replenish the shortage caused by the COVID19 pandemic, using about $85 \%$ of locally available materials. The ventilators can run continuously on a 12-voltage battery, electricity or solar Huaxia (2020). Additionally, an 18year old natural science Ethiopian student, Ezedine Kamil designed and developed a prototype ventilator, which was built using a plastic pouch and other easily available materials. Furthermore, a collaborative effort in Uganda by Kiira Motors and Makerere School of Public Health yielded the production of inexpensive ventilators Osseni (2020). The Federal Government of Nigeria at some point was in talks with Innoson Motors to manufacture low cost ventilators Osseni (2020).

\section{Semi-automatic wooden hand washing machine}

In Kenya, a nine-year-old boy Stephen Wamukota, built a semi-automatic wooden hand washing machine using wood, nails and water tank. He was subsequently honoured with a presidential award because the machine helped to curb the spread of COVID-19 in the country British Broadcasting Corporation (2020). In like manner, the government of Rwanda also deployed portable washbasins at bus stops to ensure that passengers wash their hands before boarding buses. In a similar fashion, the Ethiopian government also deployed portable washbasins at bus stops to ensure passengers wash their hands before boarding buses Alemayehou (2020). A young Ethiopian boy, Ezedine Kamil designed and developed a watch-like device to remind people not to touch their faces (any time the hand approaches the face, the device rings, reminding the wearer not to touch their face).

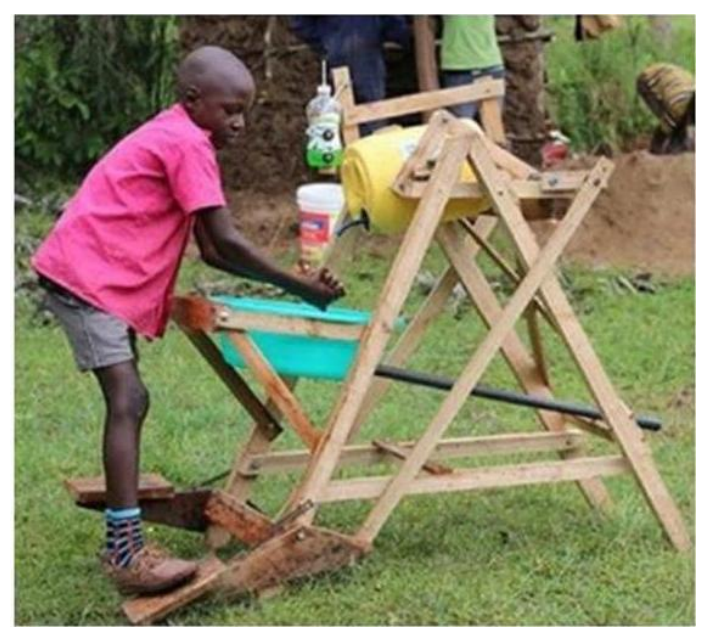

Figure 3. Semi-automatic wooden machine designed and built by a 9-year-old Kenyan boy, Stephen Wamukota to aid people to frequently wash their hands.

\section{Solar powered hand-washing machine}

Motivated by the great importance of personal hygiene in curbing the spread of COVID-19, two Ghanaian electricians developed a solar powered hand-washing basin Adamu (2020). The invention allows its users to wash their hands with soapy water, then rinse them with clean water that is automatically distributed by the touch-free system involving sensors. As the invention began to go viral, Ghana's Ministry of Environment, Science, Technology, and Innovation approached the inventors to discuss on the possibility of manufacturing the machines in larger quantities, which would be used to equip public places in cities throughout the country.

In an address to the nation in early April, President AkufoAddo commended the inventors and acknowledged that the "Ghanaian sense of enterprise and innovation is beginning to be felt." This invention inspired the invention of many similar machines all around Africa, and provided an affordable but efficient preventive measure to the population. 


\section{Robots for patient monitoring}

In order to improve the effectiveness of doctors and nurses, as well as to reduce their infection due to direct contact with infected patients, medical robots have been developed and used to curb the global pandemic in may African countries. In Rwanda, high-tech robots (named Akazuba, Ikirezi, Mwiza, Ngabo, and Urumuri) are used to administer temperature checks, monitor patient status, and keep medical records of COVID-19 patients. The robots can screen 50 to 150 people per minute, deliver food and medication to patients' rooms, capture data and notify officers on duty about detected abnormalities, fasten service delivery and help protect the lives of the valuable health workers by minimizing contact between patients and medical staff. These robots were developed through joint efforts by the Rwandan Ministry of ICT and Innovation and the United Nations Development Programme (UNDP) Salaudeen (2020).

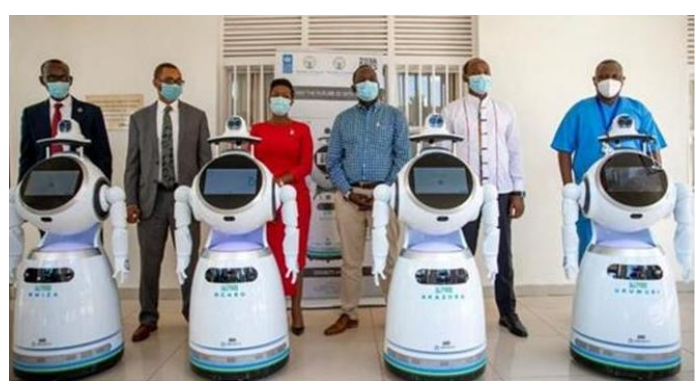

Figure 4. Robots in Rwanda for fighting COVID 19

A group of young Senegalese inventors came up with a robot doctor, which will be able to measure patients' blood pressure and temperature remotely Agency Staff (2020). The robot is guided by a mounted camera and controlled via an app. The aim of this invention is to reduce the exposure of doctors and nurses to infected patients and the use of expensive protective gear. The growing number of infected medical personnel in Senegal and other African countries has raised the alert on the unsafe practices in the hospitals and isolation centers. With the use of these robots, doctors will be able to remotely communicate with patients, potentially allowing them to treat people isolated in hard-to-reach rural areas.

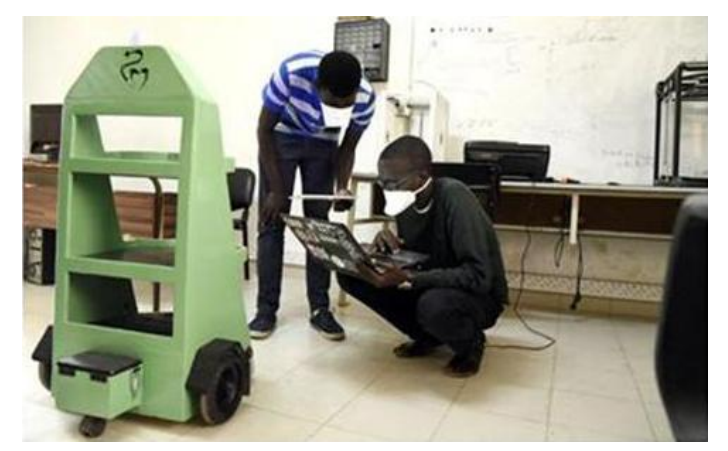

Figure 5. Docteur Car' designed by young Senegalese inventors to attend to patients remotely.

\section{Mobile Apps for check-up and monitoring}

It has been reported that delayed and shortage of testing render the fight against the novel coronavirus more challenging, which may result in more damages. Moreover, given the shortages of medical personnel in especially hard-to-reach rural areas, efficient testing and follow-up became very problematic across the continent. Hence, many mobile apps have been developed to help public health and government officials locate high-risk areas as well as follow-up with high-risk patients. Specifically, some Ghanaian scientists had developed COVID-19 symptoms tracker app RedBird (2020) which helps monitor the health status of individuals in real- time. It also provides government and public health officials with accurate details about high-risk areas. Other innovations such as the "Alerte Santé Sénégal" app Sociallinknet (2020) which aims at providing information and statistics on all diseases and more particularly viral diseases in Senegal, based solely on official sources namely the Ministry of Health and Social Action of Senegal, COUS, and WHO, were also warmly welcomed in the Senegalese medical communities.

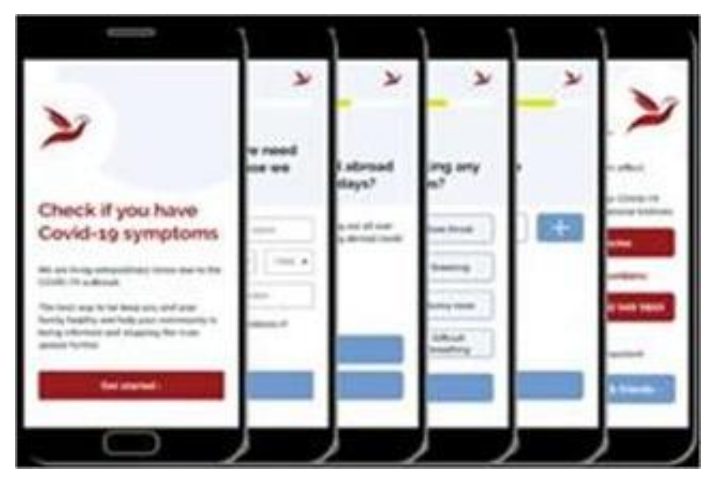

Figure 6. Redbird symptoms tracker app

\section{Drones for medical supplies and medical samples delivery}

In response to the general outcry for innovative measures in fighting the global pandemic across the continent, many AI (Artificial Intelligence) based novel approaches and inventions have been developed. Few of these innovations are as follows.

Relying on artificial intelligence, Rwanda adopted drones to deliver essential medical products, such as blood donations, around the country, which reduces the waiting time for patients in dire need. When COVID-19 hit the country on March 21st, the government swiftly shifted to using drones in order to reduce the spread of the pandemic. Subsequent to the restrictions on public transport and a nationwide lockdown, the drones were employed to deliver blood and other life-saving medications across the country. The US-based Zipline engineered autonomous drones that travel hundreds of kilometers to deliver COVID-19 tests and samples, PPEs and other vital medical supplies in a matter of minutes Kretchmer (2020). This has contributed significantly in combatting the virus as Rwanda continues to record lower values of COVID-19 infection Uwiringiyimana (2020).

Another innovation worth mentioning is the Zipline Test kits drone delivery in Ghana Zipline (2020). The company 
is equipped to transport up to 15,000 tests a day, in 300 flights, from their two collection points. With their other two drone ports, the company can serve some 2,000 rural health clinics as well as between 10-15 million residents. The new COVID-19 test sample delivery service allows the government to monitor more closely and respond to the spread of the disease in some of the country's most remote and challenging to reach areas. Before Zipline, COVID-19 test sample delivery could take between many hours to many days before a delivery truck that had collected a sufficient number of samples from rural hospitals could return to the city. COVID-19 related national shutdowns have caused the cancelation of many blood drives in countries around the world, putting a strain on supply. Zipline's ability to centralize blood stocks and distribute them just-in-time to health care providers helps to increase patient access, lower waste, and save lives.

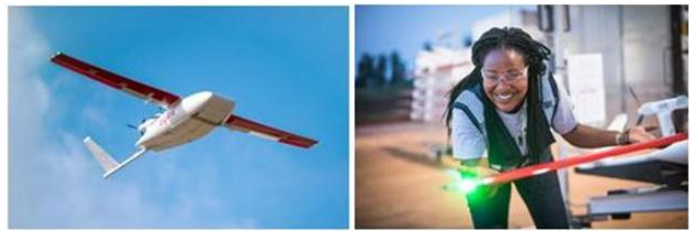

Figure 7. (a) Zipline Test kits drone delivery in flight. (b) Zipline drone at takeoff.

\section{SARS-CoV-2 Genome sequencing}

So many African scientists have been working round the clock to contribute meaningfully in a way to help researchers understand COVID-19 better. Since the onset of COVID-19 pandemic, numerous genome sequences have been successfully conducted globally. Unfortunately, only about five (5) African countries have so far made progress in this direction Edward-Ekpu (2020). The first sequence of the SARS-CoV-2 virus genome was done in Nigeria via a World Bank-supported research center EdwardEkpu (2020); Heusden (2020); Oluniyi (2020); Makoni (2020). Interestingly, DR Congo has conducted the most genome sequences from Africa. The country accounts for approximately half of the total genome sequences from Africa. The country's experience with Ebola in the recent past has helped them tremendously in collaboration with international partners to achieve this. Senegal is currently enjoying some benefits from the research capacity of Institut Pasteur de Dakar, a reputable research institute Edward-Ekpu (2020); Heusden (2020).

Not long ago, a significant landmark was attained at the Noguchi Memorial Institute for Medical Research (NMIMR) and the West African Centre for Cell Biology of Infectious Pathogens (WACCBIP) all located in Ghana. A group of talented scientists, who dedicated their time and efforts in unveiling more about COVID-19, collaborated to sequence the COVID-19 genome. This feat no doubt will aid them to gain further understanding of the virus variations Africa Research University Alliance (2020); Trial Site (2020). In South Africa, a group of scientists effectively sequenced the SARS-CoV-2 genome. The University of Western Cape's South African National Bioinformatics Institute (SANBI) in conjunction with the National Institute of Communicable
Diseases (NICD) achieved the feat. This will go a longer way to help health officials in the fight against Covid 19 spread in South Africa Heusden (2020); Cleary (2020); Turner (2020); Mushala (2020).

\section{Herbal medicine}

The remedy to the deadly COVID-19 pandemic could lie in the herbal supplement being promoted by the Madagascan government if proper clinical drug trials are carried out on the new supplement. On 8th April, 2020, Madagascar's President Andry Rajoelina made a nationwide broadcast and announced to the citizens of a potential medicinal plant discovered by scientists at the Malagasy Institute of Applied Research (IMRA), which could be the well sought after remedy to COVID-19 Sari (2020); Rick (2020). Covid Organics, the herbal cure for COVID-19 was formally presented to the world on 18th April, 2020, by Madagascar's President Andry Rajoelina who declared that the clinical trial results were decisive Sari (2020).

Subsequently, Madagascar played the role of good neighbour by supplying other African countries large quantities of Covid organics. On 8th May, 2020, Central African Republic (CAR) took delivery of large volumes of Covid organics from Madagascar Rick (2020). The government of Chad also took delivery of some consignments of Covid organics which reports say may not have been deployed to full use as the country has the highest COVID-19 related death cases presently Developmentreimagined (2020). Other African countries who received Covid organics from Madagascar inlcude: Nigeria, Comoros, Equatorial Guinea and others.

Covid-organics is actually a hot water extract from the plant Artemisia Annua which is a well-known plant in phytochemical circles Rick (2020). Interestingly, researchers have thrown their support behind Covid-organics as an effective solution to COVID-19. Sheridan Rick notes that some of the chemical compounds of Covid-organics can also be found in some other fruits and vegetables albeit in lesser quantities in comparison to Artemisia Annua. He opines that daily consumption of 1 to 2 sizeable balls of red onions will achieve the same results as Covid - organics Rick (2020).

\section{Discussions}

\section{Underlining factors contributing to different efficiency level of the emergency response mechanisms across the continent}

Despite the relatively unprepared state of most African countries towards this novel pandemic, a few countries demonstrated remarkable response performance and overall resilience. The level of preparedness, innovative potential, speed and efficiency of policy implementation, and so on, varied greatly among all the affected African nations. In a nutshell, the following paragraphs aim at revealing the critical success factors behind some of Africa's most remarkable COVID-19 responses, while providing some useful recommendations in case of future outbreaks.

The Ebola outbreak of 2014 that affected many countries in West Africa and a few in central Africa, is one of the major factors behind the remarkable preparedness of countries like Nigeria, DR Congo and Ghana. Many emergency command 
centers, isolation centers, medical training centers and many other emergency structures were built during the Ebola outbreak by some African governments and international foundations such as the Bill \& Melinda Gates Foundation. As the first cases of COVID-19 were registered in these ex-Ebola epicenters, the governments were able to leverage the presence of these already existing emergency response structures and trained personnel to react with timely and efficient measures. Many of the Ebola-affected countries had previously collaborated with international research laboratories and epidemiology experts, and therefore had more experience and practical knowledge on how to respond to any similar outbreak in aspects like lockdowns, testing, shutting up of borders, quarantining and so on.

Until recently, Africa has been slow to pave its way to major breakthroughs in the medical field and pharmaceutical industry. However, the COVID-19 pandemic has revealed the great potential of Africa in these domains. Achievements such as the sequencing of virus genomes by some African scientists, the development of efficient medical remedies in countries like Madagascar and Cameroon, the mass production of drugs like chloroquine, and so on, are just the tip of the iceberg when it comes to Africa's potential. One common factor among all the countries that could achieve impressive medical responses is the presence of active, local, state-supported and well-sponsored research laboratories. In Madagascar for example, the Malagasy Institute of Applied Research (IMRA) was the soul of Madagascar's Covidorganics. In Ghana, one key mention is the research center of the Kwame Nkrumah University of Science and Technology (KNUST). The presence of such active and sponsored research centers accelerated and amplified the response impact of these countries in the medical and pharmaceutical fields. Government support is a crucial factor to determine the survival and potency of medical research centers. For example, in Cameroon, a research laboratory owned by a local archbishop was able to come up with a herbal remedy to COVID-19, however the lack of government support limited his activities in the country.

Technological innovation and invention have become a fierce race among the leading African economies. It is of no surprise therefore that most of the inventions proposed to fight against COVID-19 outbreak were developed in African countries with relatively strong and stable economies. The market potential in such countries is the driving force behind innovations. Entrepreneurs have taken the responsibility to compete with international corporations on the design, manufacturing and supply of high-tech medical equipments such as ventilators, test-kits, masks, medical robots, apps, and so on. Another driving force of innovation is the presence of favorable tax environment and government subsidies to startups. In Cote d'Ivoire, the FEDINCI (Association of innovators and inventors of Cote d'Ivoire) supports young inventors and startups by providing them with a national platform to showcase their products, and also regularly offers subsidies and market deals. International collaborations with renowned research and development $(R \& D)$ companies have also helped some African scientists come up with outstanding innovations. An example of this is the $\$ 1$ test kit developed by the Centre Pasteur in Senegal in collaboration with the British biotech firm Mologic.
In summary, it can be inferred from the above analysis that the success of a country's response mechanisms mainly depends on: past experience, established structures, government support in R\&D and economic potential and stability. African countries should therefore learn from the COVID-19 on how to improve on their preparedness and resilience ahead of any future pandemics. Some practical recommendations would be: investing on building long lasting emergency medical structures; organizing regular trainings for medical personnel; sponsoring and active support of medical research centers and local entrepreneurs; tax reforms and increased international collaborations.

\section{Socio-economic impacts of Africa's most prominent COVID-19 innovations}

Many African countries have made wearing of face masks mandatory in public places. This is a vital measure towards preventing the spread of the novel coronavirus, which has proven its efficacy in East Asian countries such as China, Korea and Japan. The increase in demand for these products on the African continent opened doors for a huge economic market that is attracting both Chinese and local manufacturers. In China for example, more than 38,000 new companies have registered since the beginning of the year, to make and export face masks around the globe. The unfortunate result of this influx is the rising number of issues regarding mask quality and scams. Many African governments have responded to these issues by investing heavily in the industrial manufacturing of local masks. This investment is far from being a random move. The demand for face masks comes from about $50 \%$ of the African population, each of them purchasing an average of three masks. If sold for about $\$ 1$ each, Africa could earn about $\$ 1.5$ billion annually from the production of face masks with reference to its total population. These statistics, reported by MarketWatch in June 2020, show that the mass production of face masks could reach $\$ 23.81$ billion in seven years Grand View Research (2020). If this market opportunity is properly grasped by the different African countries, Africa could rapidly become the world's major producer of surgical and non-medical mask, thus creating millions of job opportunities across the continent.

Similar to the demand and supply of face masks, the manufacturing of local COVID-19 test kits, ventilators and other medical supplies, is rapidly filling up a big economic gap created by the novel pandemic. The locally made products are not only much cheaper than the imported ones, but are also better adapted to the unique requirements of the continent. The increase in the affordability of these products has led to a rise in demand for medical equipment in even smaller medical structures, which in turn triggers a rise in entrepreneurship and new businesses. These efforts have helped relieve the pressure on governments and agencies from sourcing some of these products overseas.

The multiple exploits achieved by each of the African countries in their fight against COVID-19, are having a great social impact on the African population, including a rise in pride, self-contempt and nationalism amongst African minds. The fact that Africa was able to prepare, and provide efficient response mechanisms to protect its 
people, demonstrates the great capability and potential of Africa's various sectors. Therefore, the mindset of majority of the African population is gradually changing regarding the need for, and constant reliance on western structures, medicine, technology, and so on. This was made manifest through multiple critical events that shook the face of Africa, such as, the growth in solidarity among African leaders in promoting the Covid-organics tonic from Madagascar; and the social media uproar against western laboratories trying to test their vaccines on African territory. Through most of these events, one could clearly notice Africa's walk towards complete independence and self-sufficiency.

In summary, Africa has outstandingly fought against the novel pandemic through its remarkable response mechanisms, which would definitely result in a new story for the continent after the pandemic. Specifically, the postpandemic Africa will be an emerging and stronger Africa less dependent on imports and foreign aids. Also, it will be an Africa very ready to face future pandemics with a more stable health care system.

\section{Conclusion}

In this work, the most influential strategic responses adopted by Africa to curb the COVID-19 pandemic have been enumerated. These include the socioeconomic policies, technological innovations, foreign aids, research and development and so on. These response mechanisms have been equally critically examined so as to reveal the relevance and the impact they have had so far on the fight against the pandemic across the African continent. It is observed that the great technical know-how of African governments resulted from their experience in confronting outbreaks has led to remarkable anti-epidemic mechanisms and resilience. It is our belief that this work will help researchers make fair assessments of the responses from African countries against COVID-19, which might help other countries with fragile heath care systems improve their capability of tackling epidemics.

\section{Declaration of Conflicting Interests}

The authors declare that there is no conflict of interests.

\section{Funding}

The authors received no financial support for the research, authorship, and/or publication of this article.

\section{References}

Adamu Z (2020) A solar-powered hand-washing basin encourages personal hygiene in ghana amidst coronavirus. In: CNN. Available at: https://www.cnn.com/2020/05/09/africa/ghanacoronavirus-handwash/index.html. Accessed 16 August, 2020.

Africa Research University Alliance A (2020) Ug sequences covid-19 genome in ghana. In: ARUA. Available at: https://arua.org.za/university-of-ghana/. Accessed 16 August, 2020.

Agency Staff A (2020) Senegal engineering students use robots and innovation to curb covid-19. In: Bussiness Day. Available at: https://www.businesslive.co.za/bd/world/africa/2020-0513-senegal-engineering-students-use-robots-and-innovationto-curb-covid-19/. Accessed 16 August, 2020.

Akafia M (2020) Ghana's covid 19 response: A missing piece - the saga of stranded ghanaian temporary visitors. In: Ghana Web. Available at: https://www.ghanaweb.com/GhanaHomePage/features/Ghanas-COVID-19-response-A-missing-piece-the-saga-of-strandedGhanaian-temporary-visitors-949864. Accessed 16 August, 2020.

Akorlie C (2020) Ghana's incas diagnostics expects approval for covid-19 antibody test. In: Reuters. Available at: https://www.reuters.com/article/us-health-coronavirus-ghanatest-kit-idUSKBN23H1OH. Accessed 16 August, 2020.

Alemayehou M (2020) Ethiopia battles the pandemic and its economic consequences. Available at: https://www.csis.org/analysis/ethiopia-battles-pandemicand-its-economic-consequences. Accessed 16 August, 2020.

Ben-Hur J (2020) Senegal develops one dollar rapid testing kit for covid - 19. In: The Standard. Available at: https://www.standardmedia.co.ke/kenya/article/2001369392/senegaldevelops-one-dollar-rapid-testing-kit-for-covid-19.

Booth L (2020) World bank and imf join forces to support africa through covid - 19 crisis. Available at: https://www.commercialriskonline.com/world-bank-andimf-join-forces-to-support-africa-through-covid-19-crisis/. Accessed 16 August, 2020.

British Broadcasting Corporation B (2020) Coronavirus: Ten african innovations to help tackle covid-19. In: BBC News. Available at: https://www.bbc.com/news/world-africa53776027. Accessed 16 August, 2020.

Cascella M, Rajnik M, Cuomo A, Dulebohn SC and Napoli RD (2020) Features, evaluation and treatment coronavirus (covid19).

Centers for Disease Control \& prevention C (2020) Past pandemics. Available at: https://www.cdc.gov/flu/pandemicresources/basics/past-pandemics.html. Accessed 12 August, 2020.

Cleary K (2020) How scientists found the fingerprint behind south africa's covid-19 virus. In: Health24. Available at: https://www.health24.com/Medical/Infectiousdiseases/Coronavirus/how-scientists-found-the-fingerprintbehind-south-africas-covid-19-virus-20200411-3. Accessed 16 August, 2020.

Developmentreimagined (2020) Africa's covid - 19 tests and deaths: why so different? In: Development Reimagined. Available at: https://developmentreimagined.com/2020/06/19/africascovid19-tests-and-deaths/. Accessed 16 August, 2020.

Devermont J and Mukulu T (2020) South africa's bold response to the covid -19 pandemic. Available at: https://www.csis.org/analysis/south-africas-bold-responsecovid-19-pandemic. Accessed 13 August, 2020.

Edward-Ekpu U (2020) Africa may lose out on covid-19 genomic sequencing for vaccines. In: Quartz Africa. Available at: https://qz.com/africa/1836417/africa-may-loseout-on-covid-19-genomic-sequencing-for-vaccines/. Accessed 16 August, 2020.

Effah K (2020) 10 companies and individuals who have donated towards ghana's covid-19 fund so far. In: 
Yen. Available at: https://yen.com.gh/152331-10-companiesindividuals-donated-ghanas-covid-19-fund-far.html. Accessed 16 August, 2020.

Effective States \& Inlcusive Development E (2020) Zambia's response to covid - 19. Available at: http://www.effectivestates.org/zambias-response-to-covid-19/. Accessed 16 August, 2020.

Emmanuel D (2020) Bua donates 1 billion cash to support covid - 19 response in nigeria. In: Politics Nigeria. Available at: https://politicsnigeria.com/bua-donates-1-billioncash-to-support-covid-19-response-in-nigeria/. Accessed 16 August, 2020.

Fair Wear F (2020) Covid-19 impact and responses: Tunisia. In: Fair Wear. Available at: https://www.fairwear.org/covid-19dossier/worker-engagement-and-monitoring/country-specificguidance/tunisia. Accessed 16 August, 2020.

Fletcher B (2020) The economic impact of covid-19 on sub-saharan africa. Available at: https://www.controlrisks.com/ourthinking/insights/the-economic-impact-of-covid-19-on-subsaharan-africa. Accessed 16 August, 2020.

Ghana Web G (2020) Ghanaian times: Covid-19 and innovation: The new normal. In: Ghana Web. Available at: https://www.ghanaweb.com/GhanaHomePage/NewsArchive/Gh Times-COVID-19-and-innovation-The-new-normal-938515. Accessed 16 August, 2020.

Grand View Research G Inc (2020) Disposable face mask market going to hit $\$ 23.81$ billion by 2027 . In: Market Watch. Available at: https://www.marketwatch.com/pressrelease/disposable-face-mask-market-going-to-hit-2381billion-by-2027-exclusive-report-by-grand-view-research-inc2020-06-27. Accessed 16 August, 2020.

Guo YR, Cao Q, Hong Z, Tan Y, Chen S, Jin H, Tan K, Wang DY and Yan Y (2020) The origin, transmission and clinical therapies on coronavirus disease 2019 (covid-19) outbreak ? an update on the status. Military Medical Research 7.

Guti'errez-Romero R (2020) Conflict in africa during covid-19: Social distancing, food vulnerability and welfare response. ERN: Human Resources in Developing Economies (Topic) .

Heusden PV (2020) Africa joins the race to trace covid 19 with genomics. In: The Conversation. Available at: https://theconversation.com/africa-joins-the-race-to-tracecovid-19-with-genomics-136427. Accessed 16 August, 2020.

Huaxia (2020) Kenyan university launches contact tracing app, ventilators to help address covid-19 pandemic. In: Xinhuanet. Available at: http://www.xinhuanet.com/english/202005/07/c_139035989.htm. Accessed 16 August, 2020.

Ihekweazu C and Agogo E (2020) Africa's response to covid-19. BMC Med 18.

International Center for Not Profit Law I (2020) African government responses to covid - 19. Available at: https://www.icnl.org/post/analysis/african-governmentresponse-to-covid-19. Accessed 16 August, 2020.

International Institute for Democracy \& Electoral Asistance I (2020) Global overview of covid-19 impact on elections. Available at: https://www.idea.int/news-media/multimediareports/global-overview-covid-19-impact-elections. Accessed 16 August, 2020.
International Monetary Fund I (2020) Policy response to covid - 19. Available at: https://www.imf.org/en/Topics/imfand-covid19/Policy-Responses-to-COVID-19. Accessed 16 August, 2020.

Jester BJ, Uyeki TM and Jernigan DB (2018) Readiness for responding to a severe pandemic 100 years after 1918. American Journal of Epidemiology 187: 2596 - 2602.

Kantis C, Kiernan S and Bardi JS (2020) Updated: Timeline of the coronavirus. In: thinkglobalhealth. Available at: https://www.thinkglobalhealth.org/article/updated-timelinecoronavirus. Accessed 12 August, 2020.

KPMG (2020a) Cameroon: Government and institution measures in response to covid-19. Available at: https://home.kpmg/xx/en/home/insights/2020/04/cameroongovernment-and-institution-measures-in-response-tocovid.html. Accessed 16 August, 2020.

KPMG (2020b) Chad: Government and institution measures in response to covid-19. Available at: https://home.kpmg/xx/en/home/insights/2020/04/chadgovernment-and-institution-measures-in-response-tocovid.html. Accessed 16 August, 2020.

KPMG (2020c) Democratic republic of congo: Government and naianinstitution measures in response to covid-19. Available at: https://home.kpmg/xx/en/home/insights/2020/04/drcgovernment-and-institution-measures-in-response-tocovid.html. Accessed 16 August, 2020.

KPMG (2020d) Egypt: Government and institution measures in response to covid-19. Available at: https://home.kpmg/xx/en/home/insights/2020/04/egyptgovernment-and-institution-measures-in-response-tocovid.html. Accessed 16 August, 2020.

KPMG (2020e) Zambia: Government and institution measures in response to covid-19. Available at: https://home.kpmg/xx/en/home/insights/2020/04/zambiagovernment-and-institution-measures-in-response-tocovid.html. Accessed 16 August, 2020.

Kretchmer H (2020) How drones are helping to battle covid-19 in africa - and beyond. In: The European Sting. Available at: https://europeansting.com/2020/05/10/how-drones-arehelping-to-battle-covid-19-in-africa-and-beyond/. Accessed 16 August, 2020.

Loembé MM, Tshangela A, Salyer SJ, Varma JK, Ouma AEO and Nkengasong JN (2020) Covid-19 in africa: the spread and response. Nature Medicine 26: 999-1003.

Maayaki B (2020) Bishops in ghana donate to national covid - 19 fund. In: Vatican News. Available at: https://www.vaticannews.va/en/church/news/202005/ghanaian-episcopal-conference-donates-to-national-covid19-fund.html. Accessed 16 August, 2020.

Maida LS (2020) China and africa's solidarity against covid-19. Available at: https://www.msn.com/en-za/news/other/chinaand-africa-e2-80-99s-solidarity-against-covid-19/arBB15Rb7w. Accessed 16 August, 2020.

Makoni M (2020) Africa contributes sars-cov-2 sequencing to covid-19 tracking. In: The Scientist. Available at: https://www.the-scientist.com/news-opinion/africacontributes-sars-cov-2-sequencing-to-covid-19-tracking67348. Accessed 16 August, 2020. 
Maringira G (2020) Covid - 19: social distancing and lockdown in black townships in south africa. Available at: https://kujengaamani.ssrc.org/2020/05/07/covid-19-social-distancing-andlockdown-in-black-townships-in-south-africa/. Accessed 13 August, 2020.

Masbah M and Jacobs A (2020) Can morocco effectively handle the covid-19 crisis? Available at: https://www.chathamhouse.org/expert/comment/can-moroccoeffectively-handle-covid-19-crisis-1. Accessed 13 August, 2020.

Mushala (2020) Whole-genome sequence of the severe acute respiratory syndrome coronavirus 2 (sars-cov2) obtained from a south african coronavirus disease 2019 (covid - 19) patient. In: Virological. Available at: https://virological.org/t/wholegenome-sequence-of-the-severe-acute-respiratory-syndromecoronavirus-2-sars-cov-2-obtained-from-a-south-africancoronavirus-disease-2019-covid-19-patient/452. Accessed 16 August, 2020.

Near East South Asia N (2020) Covid-19 in algeria: Responses and future outlook. Available at: https://nesa-center.org/covid-19in-algeria-responses-and-future-outlook/. Accessed 16 August, 2020.

Oluniyi PE (2020) In: Virological. Available at: https://virological.org/t/first-african-sars-cov-2-genomesequence-from-nigerian-covid-19-case/421. Accessed 16 August, 2020.

Onyenaucheya A (2020) Nigerians demand accountability of donated funds, facilities to fight covid-19. In: The Guardian. Available at: https://guardian.ng/news/nigerians-demandaccountability-of-donated-funds-facilities-to-fight-covid-19/. Accessed 16 August, 2020.

Osseni IA (2020) Covid-19 pandemic in sub-saharan africa: preparedness, response, and hidden potentials. Tropical Medicine and Health 48.

Otu AA, Ameh S, Osifo-Dawodu E, Alade E, Ekuri S and Idris J (2017) An account of the ebola virus disease outbreak in nigeria: implications and lessons learnt. BMC Public Health 18.

Otu AA, Ebenso B, Labonté R and Yaya S (2020) Tackling covid19: Can the african continent play the long game? Journal of Global Health 10.

Prison Insider P (2020) Africa: coronavirus, prison fever. In: Prison Insider. Available at: https://www.prisoninsider.com/en/articles/afrique-coronavirus-la-fievre-desprisons\#egypte-5e81fe6857976. Accessed 16 August, 2020.

RedBird (2020) Announcing redbird's daily covid19 check-in and symptom tracker. Available at: https://www.redbird.co/2020/03/26/announcing-redbirdsdaily-covid-19-check-in-and-symptom-tracker/. Accessed 16 August, 2020.

Rick S (2020) Does madagascar's herbal remedy covid-organics work. In: Medium. Available at: https://towardsdatascience.com/does-madagascars-covidorganics-work-74f577eb415b. Accessed 16 August, 2020.

Salaudeen A (2020) Rwanda has enlisted anti-epidemic robots in its fight against coronavirus. In: CNN. Available at: https://edition.cnn.com/2020/05/25/africa/rwandacoronavirus-robots/index.html. Accessed 16 August, 2020.

Sari E (2020) Coronavirus: the miracle remedy touted by madagascar's rajoelina. In: The Africa Report. Available at: https://www.theafricareport.com/26599/coronavirus-themiracle-remedy-touted-by-madagasars-rajoelina/. Accessed 16 August, 2020.

Sarker S (2020) Covid-19: Senegal and nigeria fighting the good fight. In: Dhaka Tribune. Available at: https://www.dhakatribune.com/feature/2020/03/19/covid-

19-senegal-and-nigeria-fighting-the-good-fight. Accessed 16 August, 2020.

Schneidman W, McLaren M and Taylor C (2020a) South africa's economic response to the covid-19 pandemic (part iii). Available at: https://www.covafrica.com/2020/04/southafricas-economic-response-to-the-covid-19-pandemic-partiii/. Accessed 16 August, 2020.

Schneidman W, McLaren M and Taylor C (2020b) South africa's economic response to the covid - 19 pandemic. Available at: https://www.covafrica.com/2020/04/south-africas-economicresponse-to-the-covid-19-pandemic/. Accessed 13 August, 2020.

Sociallinknet (2020) Alerte santé sénégal, l'appli intelligente qui vous informe sur la covid-19. Available at: https://www.socialnetlink.org/2020/04/02/alerte-sante-

senegal-lappli-intelligente-qui-vous-informe-sur-la-covid-19/. Accessed 16 August, 2020.

The Punch T (2020) Covid-19: Military releases 21 hospitals to states for treatment. Available at: http://www.msn.com/enxl/africa/nigeria/covid-19-military-releases-21-hospitals-tostates-for-treatment/ar-BB14OZig. Accessed 16 August, 2020.

The World Bank W (2020a) Egypt: World bank provides us $\$ 50$ million in support of coronavirus emergency response under new fast-track facility. Available at: https://www.worldbank.org/en/news/pressrelease/2020/05/17/egypt-world-bank-provides-us-50-millionin-support-of-coronavirus-emergency-response-under-newfast-track-facility. Accessed 16 August, 2020.

The World Bank W (2020b) World bank approves \$20 million for senegal to fight covid-19. Available at: https://www.worldbank.org/en/news/pressrelease/2020/04/02/world-bank-approves-20-million-forsenegal-to-fight-covid-19. Accessed 16 August, 2020.

The World Bank W (2020c) World bank group supports ghana's covid-19 response. Available at: https://www.worldbank.org/en/news/pressrelease/2020/04/02/world-bank-group-supports-ghanascovid-19-response. Accessed 16 August, 2020.

The World Bank W (2020d) World bank makes us $\$ 35$ million available to support tunisia through coronavirus (covid-19) crisis. Available at: https://www.worldbank.org/en/news/pressrelease/2020/04/30/world-bank-makes-us35-million-availableto-support-tunisia-through-coronavirus-covid-19-crisis. Accessed 16 August, 2020.

Trial Site T (2020) Ghanaian scientists successfully sequence sars-cov-2 virus genomes. In: trialsitenews. Available at: $\quad$ https://www.trialsitenews.com/ghanaian-scientistssuccessfully-sequence-sars-cov-2-virus-genomes/. Accessed 16 August, 2020.

Turner KJ (2020) Sa scientists make important covid-19 discovery. In: IOL. Available at: https://www.iol.co.za/news/southafrica/western-cape/sa-scientists-make-important-covid-19discovery-46330621. Accessed 16 August, 2020. 
United Nations U (2020a) Covid-19 in africa: Protecting lives and economies. Available at: https://www.uneca.org/publications/covid-19-africaprotecting-lives-and-economies. Accessed 12 August, 2020.

United Nations U (2020b) The economic impact of covid-19 on african cities likely to be acute through a sharp decline in productivity, jobs and revenues, says eca. Available at: https://www.uneca.org/stories/economic-impact-covid19-african-cities-likely-be-acute-through-sharp-declineproductivity. Accessed 13 August, 2020.

United Nations U (2020c) Policy brief: Impact of covid-19 in africa. Available at: https://www.uneca.org/publications/policy-briefimpact-covid-19-africa. Accessed 13 August, 2020.

US Embassy Morocco EM (US (2020) The united states provides essential protective equipment \& supplies to morocco's national institute of hygiene. In: U.S. Embassy in Morocco. Available at: https://ma.usembassy.gov/the-unitedstates-provides-essential-protective-equipment-supplies-tomoroccos-national-institute-of-hygiene/. Accessed 16 August, 2020.

US Embassy Tunisia ET (US (2020) Covid-19 and the u.s. response. In: U.S. Embassy in Tunisia. Available at: https://tn.usembassy.gov/covid19-us-response/. Accessed 16 August, 2020.

US Embassy Zambia EZ (US (2020) Fact sheet: U.s. government's response to covid-19 in zambia. In: U.S. Embassy in Zambia. Available at: https://zm.usembassy.gov/fact-sheet-us-governments-response-to-covid-19-in-zambia/. Accessed 16 August, 2020.

Uwiringiyimana C (2020) Covid-19: Rwanda uses drones to help catch lockdown transgressors. In: The Star. Available at: https://www.thestar.com.my/tech/technews/2020/04/18/covid-19-rwanda-uses-drones-to-helpcatch-lockdown-transgressors. Accessed 16 August, 2020.

World Bank Group W (2020) Assessing the economic impact of covid - 19 and policy responses in sub -saharan africa. Available at: http://pubdocs.worldbank.org/en/795471589952285352/05222020Africas-Pulse-2020-April-Cesar-Calderon.pdf. Accessed 13 August, 2020.

World Health Organization W (2020) Who coronavirus disease (covid-19) dashboard. Available at: https://covid19.who.int/. Accessed 10 November, 2020.

Xinhua (2020) Egypt receives new batch of anti-coronavirus medical aid from china; turkey's covid-19 cases surpass 148,000. Available at: https://www.shine.cn/news/world/2005178261/. Accessed 16 August, 2020.

Zawya (2020) Egypt parliament's legislative committee approves emergency law amendments. Available at: https: //www.zawya.com/mena/en/legal/story/ Egypt_parliaments_legislative_committee_ approves_emergency_law_amendments-SNG_ 172662541/. Accessed 13 August, 2020.

Zipline (2020) Zipline's covid-19 response. Available at: https://www.flyzipline.com/covid-19/. Accessed 16 August, 2020. 